\title{
geosciences
}

ISSN 2076-3263

www.mdpi.com/journal/geosciences

Communication

\section{The Extinction of the Conulariids}

\section{Spencer G. Lucas}

New Mexico Museum of Natural History, 1801 Mountain Road N.W., Albuquerque, NM 87104, USA; E-Mail: spencer.lucas@state.nm.us; Tel.: +1-505-841-2873; Fax: +1-505-841-2808

Received: 22 February 2012; in revised form: 12 March 2012 / Accepted: 15 March 2012 /

Published: 22 March 2012

\begin{abstract}
Conulariids are unusual extinct metazoans most often considered to be a group of scyphozoan cnidarians or close relatives. Generally, the temporal range of conulariid fossils is perceived to be late Precambrian or Cambrian to Triassic, though a supposed Cretaceous conulariid from Peru was published 46 years ago. A re-evaluation of this fossil indicates it is not a conulariid, but instead a pinnacean bivalve (Pinna sp.), confirming that the geologically youngest conulariids are of Late Triassic age. However, a review of the Triassic conulariid fossil record indicates it is very sparse, with only eight published records. It does not provide a reliable basis for analyzing the structure of conulariid extinction. Nevertheless, conulariid extinction still appears to have taken place very close to the end of the Triassic. The cause of conulariid extinction may have been the onset of the Mesozoic marine revolution, in which durivorous predators developed new mechanisms for preying on the epifaunal benthos, including the conulariids.
\end{abstract}

Keywords: conulariid; extinction; Triassic; Peru; Mesozoic marine revolution

\section{Introduction}

Conulariids are extinct marine metazoans with a fossil record that definitely extends from the Late Cambrian to the Late Triassic, almost 300 million years. Diverse literature on conulariids has primarily focused on their anatomy, phylogenetic relationships and mode of life (paleoecology) (see especially references cited by Leme et al. [1]). Recent phylogenetic analyses advocate a near consensus view that conulariids are scyphozoan cnidarians or their close relatives [1], though conulariids are considered a distinct phylum by some workers. Most paleoecological analyses identify conulariids as benthic organisms that were attached to or embedded in either soft or hard substrates. 
What has received little discussion is conulariid extinction, which has long been perceived of as an end-Triassic event [2]. Indeed, Nudds and Sepkoski [3] identified Conulariida as a phylum that became extinct as part of the end-Triassic mass extinction, one of the supposed "big five" mass extinctions of the Phanerozoic. Nevertheless, a published record of a supposed Cretaceous conulariid from Peru [4,5] suggests a greater longevity of the conulariids, but it has either been ignored, overlooked or summarily dismissed without re-evaluation. My purpose here is to explore the subject of conulariid extinction by re-evaluating the supposed Cretaceous record and by critically reviewing their Triassic record to answer the questions of when and how the conulariids suffered extinction.

\section{Conulariid Anatomy, Affinities, Fossil Record and Paleoecology}

The typical conulariid animal (Figure 1) had a phosphatic (apatite) skeleton that was a steep, four-sided pyramid, usually less than $10 \mathrm{~cm}$ long but in some cases up to $40 \mathrm{~cm}$ long. Ornamentation of the skeleton consisted of transverse ridges (ribs), longitudinal ridges and/or fine nodes (Figure 1). The corners of the pyramid have sulci, and the narrow end (apex) of the pyramid is either pointed or ends at an outwardly convex, smooth wall, referred to as the apical wall or the schott.

Figure 1. (A) Generalized drawing of the conulariid test; (B) Distal end with triangular flaps raised; (C) Detail of part of exterior of test showing ornamentation. Modified from [6].

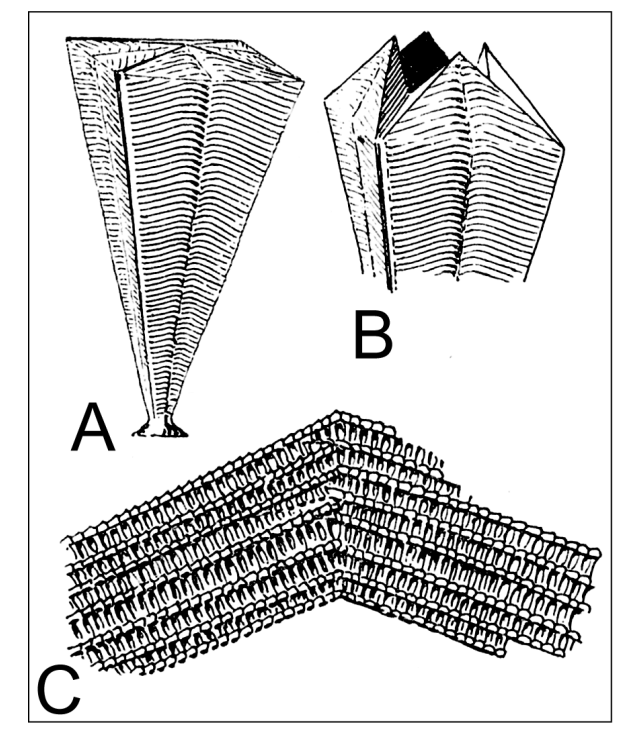

As Van Iten et al. [7] stressed, conulariids are a problematic fossil group whose affinities are not readily determined. They have most recently been viewed as either a distinct phylum or as scyphozoan cnidarians or their close relatives. The latter view is more prevalent, but regardless of their affinities, conulariids are a distinct, monophyletic group of metazoans [1,7].

Conulariid fossils are known from all of the continents except Antarctica. The oldest possible conulariid is of Ediacaran age [8], and the group is definitely known from Cambrian fossils. Conulariid diversity was never high, with no more than eight conulariid genera being recognized in any geological period. The zenith of conulariid diversity (Figure 2) was during the Ordovician-Devonian when five or more genera were present [9]. Diversity was lower during the Carboniferous-Permian, about four 
genera, and then there was a diversity drop to one or two genera in the Triassic, the lowest level since the Cambrian (Figure 2). The youngest bona fide conulariid is of Triassic age.

Figure 2. Conulariid generic diversity through time as plotted by [1]. Note that the diagram shows two Triassic genera, but Van Iten [10] suggests that there is only one Triassic genus.

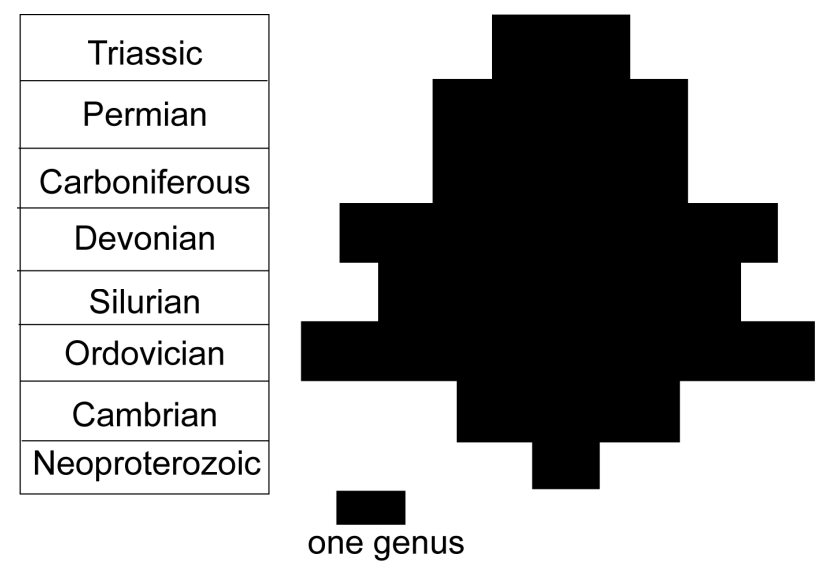

In part because of their perceived relationship to scyphozoans, some workers have inferred that the conulariid mode of life was free swimming $[11,12]$. Contrary to this conclusion, a wealth of evidence indicates that conulariids were epifaunal benthos. The data to support this conclusion are taphonomic and functional anatomic, and have been well represented by various workers, e.g., [13-17].

\section{Cretaceous Conulariid}

For nearly half a century, a supposed Cretaceous conulariid (Figure 3A) has been in the paleontological literature [4,5]. It has been dismissed by Waterhouse [18] and Babcock [19,20] who, without examining the fossil, suggested it is more likely a specimen of the bivalve Pinna. This supposed Cretaceous conulariid record is a single fossil collected by petroleum geologist Harvey Bassler (1882-1950) in September 1924 from gray siltstone and shale at a locality he named "fossil creek" near the Marañón River in northern Peru. Willard [4] termed the general locality the Pongo de Manseriche, which is a gorge in the Peruvian eastern Cordillera along which Cretaceous marine strata are exposed by the Marañon geanticline. The fossil assemblage from these rocks associated with the "conulariid" fossil is bivalve dominated, and includes characteristic Cretaceous bivalve genera such as Inoceramus, Exogyra, Pinna, Ostrea, Plicatula, Lima and Crassatella, as well as fragmentary fossils of gastropods and ammonoids, and Willard [4] judged it to be of Late Cretaceous age.

Willard [4] described the fossil-bearing interval at "fossil creek" as very fossiliferous shale above quartzite and termed it the "Manseriche dark gray shale and limestone," approximately $900 \mathrm{~m}$ thick, which is overlain by sandstones, conglomerates and clastic red beds. This lithostratigraphic description of the "Manseriche dark gray shale and limestone" and adjacent strata well matches that of the Celendín Formation in this part of Peru [21,22].

Willard [4] listed no age diagnostic ammonoids from "fossil creek," but the bivalves he listed include Ostrea, Inoceramus, Roudairia and Plicatulopecten, genera well known from the lower part of the Celendín Formation [21,22]. The Celendín Formation encompasses marine rocks deposited in the 
east-Peruvian basin during a late Turonian-early Coniacian transgression [23]. However, given the imprecise stratigraphic and geographic provence of "fossil creek" provided by Willard [4], I only conclude tentatively that the "conulariid" and associated fossils that Bassler collected from "fossil creek" are from the lower part of the Celendín Formation, and that they are close in age to the Turonian-Coniacian boundary.

Figure 3. (A) Comparison of USNM 545347, a supposed Cretaceous conulariid from Peru; (B) NMMNH P-62970, a Cretaceous specimen of the bivalve Pinna from West Texas, USA.
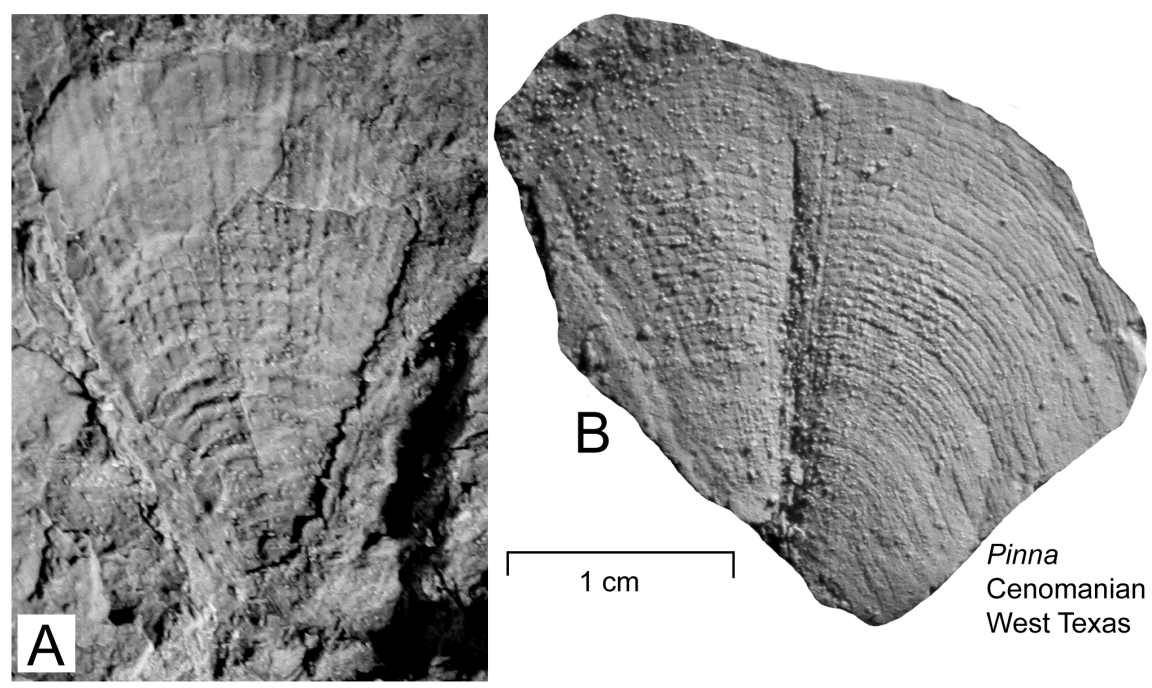

Willard [4] published a photograph of the "conulariid" fossil from Peru, and Willard [5] published a photograph and brief description of the "conulariid." The fossil is now in the collection of the National Museum of Natural History, Smithsonian Institution, Washington, DC, USA, catalogued as USNM 545347 (Figure 3A). It is preserved on a piece of dark gray shale identical to the matrix of associated marine Cretaceous bivalves from "fossil creek." Therefore, I am certain that it is not a Paleozoic fossil accidentally mixed with Cretaceous fossils, but a fossil from the same strata that produced the Cretaceous bivalve taxa listed by Willard [4] from the "fossil creek" locality.

Willard [5] described USNM 545347 as a "nearly complete, isolated pyramid face, relatively low and broad" and noted that it has "about 30 radiating, straight, longitudinal ridges or ribs that are intersected by slightly arcuate cross ridges" and that "the ribs are nodose... [and] in plan view, the nodes are broadly oval". He further stated that "a small proportion of the face is exfoliated, exposing [the] reverse (interior) surface" and that "the apex of the pyramid is blunt; the distal end arched concentric to the cross ridges". He also judged that "the ridges between the pyramid sides... are fairly prominent." Willard [5] concluded that among conulariids, USNM 545347 is most similar to Pseudoconularia Miller and Gray.

My examination of USNM 545347 indicates that Willard's description is accurate, if one assumes it is a conulariid test that is being described. However, features of the specimen that preclude identifying it as a conulariid are: (1) the shell is not phosphatic, it is calcareous; (2) the overall shape of the shell is of a wedge that widens rapidly over a short distance (the angle between the long sides is $\sim 55^{\circ}$ ) and has a convex "distal" edge; (3) the shell is concave internally and there is no evidence of sulci along the edge of the shell; (4) the pattern of ornamentation only superficially resembles that of a conulariid, 
particularly the arcuate "cross ridges," which are not continuous or prominent, but instead are discontinuous and slightly undulating, and the numerous and prominent radial ridges. These are all features either not present in conulariids or, if present in conulariids, they are developed differently.

Instead, I conclude that both Waterhouse [18] and Babcock [19] were correct to suggest that USNM 545347 is a fossil of the bivalve Pinna. Pinna is a well known, cosmopolitan genus of marine bivalve with a stratigraphic range of Carboniferous-Pleistocene, still has extant representatives, and is locally common in Cretaceous marine strata. Indeed, Willard [4] reported Pinna from the Cretaceous collections made in Peru by Bassler. Characteristic features of Pinna are its wedge-shaped to ham-shaped valves that have radial ribs, some small nodes and slightly undulose growth lines [24]. Indeed, direct comparison of USNM 545347 to a same-sized specimen of Pinna from the Upper Cretaceous (middle Cenomanian) Mancos Formation of the Franklin Mountains near El Paso, Texas [25] indicates close similarity (Figure 3). Although USNM 545347 differs from the West Texas Pinna in details of the fine ornamentation (which suggest to me that they represent different species of Pinna), their overall similarity is striking, especially their wedge shape, small nodes, radial lines and undulose concentric ridges (lirae). I conclude, based on re-examination of USNM 545347, that other workers were correct to assign it to Pinna. It is not a conulariid fossil from the Cretaceous of Peru.

\section{Triassic Conulariids}

Thomas [26] well summarized the Triassic conulariid record, describing it as "the very rare Triassic conularids described from Japan, Kashmir, New Zealand, and Europe". Indeed, my review of the published literature recovered only eight documented Triassic records of conulariids (Table 1). Ironically, the first published record of a Mesozoic conulariid by Argéliez [27] was of a form named "Conularia cancellata" from the Lower Jurassic of France. This fossil was never documented, the species name was used by Sandberger [28] for a bona fide Paleozoic conulariid, and the supposed French Jurassic record has been widely dismissed [29-31]. The published Triassic conulariid records are:

1. Conularia triadica Bittner, 1890 comes from the Hellen Kalk in the Hohen Wand (Wiener Neustadt) of Austria, strata of Norian age [29,30,32].

2. Osswald [30] named Conularia stromeri for specimens from the classic Kössen Beds (type strata of the Rhaetian stage) in Austria.

3. Diener [33] described a single specimen as Conularia sp. from the "Muschelkalk" (Ptychites layer) east of Guryul Ravine in Kashmir. These are strata of Middle Triassic age that cross the Anisian-Ladinian boundary [34].

4. Trechmann [35] documented a specimen from the Carnian ("Otamitan") strata of the Hokonui Hills in New Zealand.

5. Sugiyama [36] named Conulariopsis quadrata from Lower Triassic strata (Induan/late Griesbachian "Ophiceras beds") in the Ozika Peninsula of Japan.

6. Waterhouse [18] restudied the material from New Zealand described by Trechmann [35] and assigned it to a new species, Paraconularia mataurensis. He also assigned material from the Rhaetian ("Otapirian") of New Zealand to that species. 
7. Waterhouse [18] named the new genus and species Flectoconularia abapertura for specimens from the Carnian ("Otamitan") of New Zealand and also documented indeterminate material of Carnian age.

8. Hagdorn and Campbell [37] listed Paraconularia mataurensis from the Rhaetian of New Caledonia.

Table 1. Published records of Triassic conulariids (in geologic time order) using the original published taxonomic names without revision.

\begin{tabular}{lllll}
\hline Taxon & Location & Age & Publication & Reference \\
\hline Paraconularia matauraensis & New Zealand & Rhaetian & Waterhouse (1979) & {$[18]$} \\
Paraconularia matauraensis & New Caledonia & Rhaetian & Hagdorn \& Campbell (1993) & {$[37]$} \\
Conularia stromeri & Austria & Rhaetian & Osswald (1918) & {$[30]$} \\
Flectoconularia abapertura & New Zealand & Carnian & Waterhouse (1979) & {$[18]$} \\
Indeterminate conulariid & New Zealand & Carnian & Waterhouse (1979) & {$[18]$} \\
Conularia triadica & Austria & Carnian & Bittner (1890) & {$[29]$} \\
Conularia sp. & Kashmir & Anisian-Ladinian & Diener (1913) & {$[33]$} \\
Conulariopsis quadrata & Japan & Induan & Sugiyama (1942) & {$[36]$} \\
\hline
\end{tabular}

There is also an unpublished conulariid record from the Norian of northeastern Germany [38]. The published Triassic record of conulariids thus can be summarized as one Early Triassic record, one Middle Triassic record and six Late Triassic records (Table 1, Figure 4). If we use the taxa reported, the generic diversity increases during the Triassic from one (Early-Middle Triassic) to two (Late Triassic). However, H. Van Iten [10] informs me that he believes all of the documented Permian and Triassic conulariids belong to one genus, Paraconularia, in which case only one genus of conulariid existed during the 50 million years of Triassic time.

Figure 4. Triassic world map showing distribution of published records of Triassic conulariids. See Table 1 and text for more details about these records.

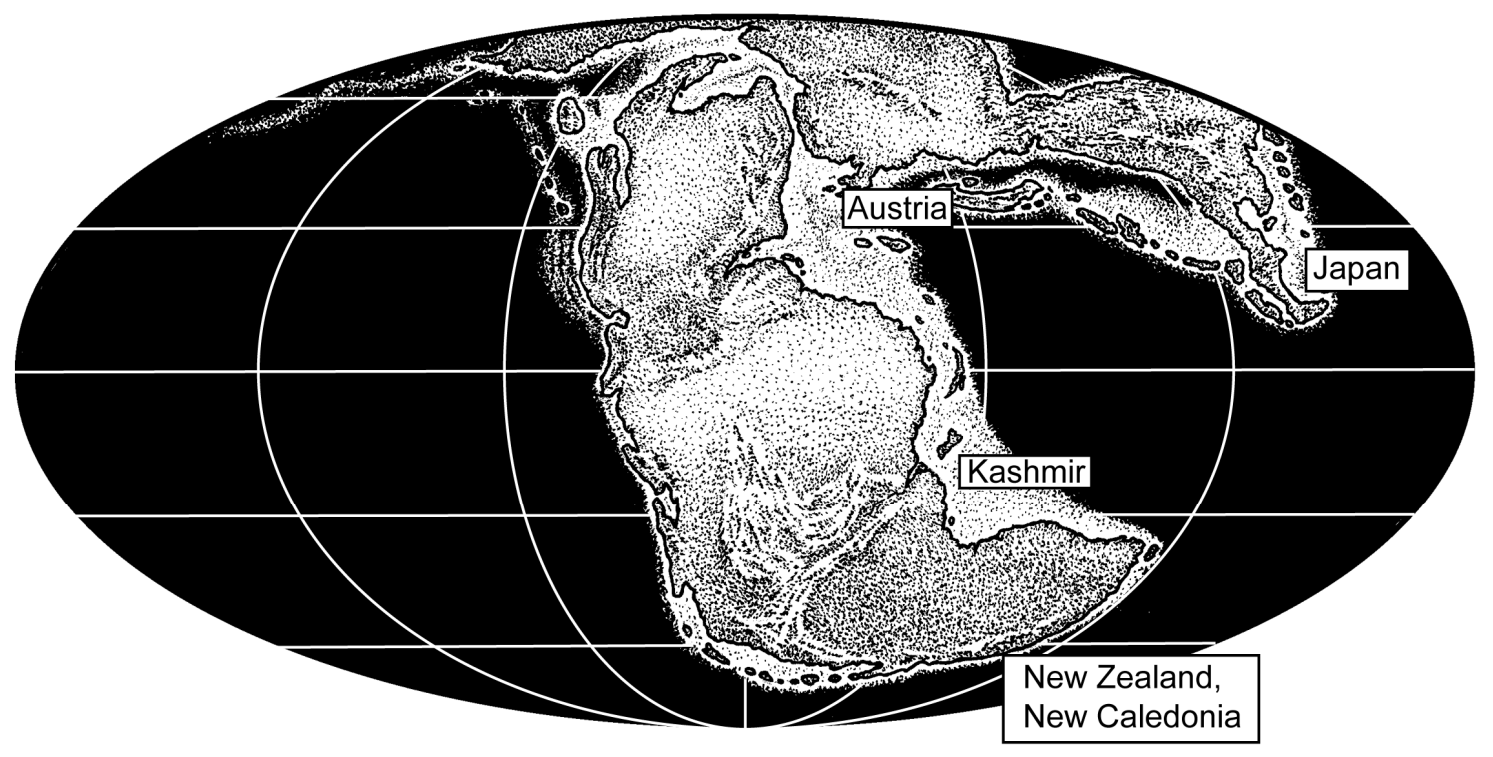




\section{Conulariid Extinction}

Conulariids were a long-lived ( $\sim 350$ million year duration) group of marine metazoans that were of relatively low diversity, typically rare as fossils, but sometimes abundant, in a range of marine settings. However, their Triassic record is remarkably sparse-eight published reports that encompass most of the 50 million years of Triassic time and come from far-flung localities in eastern Pangea, Tethys and Panthalassa (Table 1, Figure 4). Tanner et al. [2] noted that "nothing is known of the detailed structure of the extinction [of conulariids]" because their Triassic fossil record is so sparse that it does "not provide an adequate database with which to evaluate patterns of their extinction." Indeed, all the Triassic record of conulariids may indicate about their extinction is that they disappeared during the last Triassic stage (Rhaetian), but it is not even clear that they became extinct at the very end of Rhaetian time and thus were part of a "terminal-Triassic extinction."

Given their sparse Triassic record, no definitive analysis of the pattern and process of conulariid extinction seems possible. However, I do believe a few suggestions (or "talking points") should be considered:

1. There is an apparent reduction in conulariid abundance, diversity (but see [10]) and distribution across the Permo-Triassic boundary (Figure 2; also compare Table 1 to Table 1 in [39]). This may indicate a substantial extinction of conulariids during the Permo-Triassic mass extinction, and that they persisted as a "relict" group throughout the Triassic. Such relict survivors (for example, trilobites and fusulinids) are known from the interval between the end-Guadalupian extinction and the end-Permian extinction, though this interval is an order of magnitude shorter than the Triassic Period.

2. Waterhouse [18] and Weldon and Shi [39] argued that the paleogeographic distribution of Permian conulariids indicates that they preferred cold to cool-water, poleward regions. Their Triassic distribution (Figure 4), however, does not support such an inference, though their relative abundance in New Zealand-New Caledonia during the Late Triassic could be a hint at such a preference. Nevertheless, with so few records, it seems injudicious to suggest anything about the paleobiogeography and habitat preferences of Triassic conulariids.

3. The final extinction of the conulariids could have been a result of the "Mesozoic marine revolution," which refers to an increase in predation pressure (especially by durviorous predators such as some gastropods) that drove a turnover in marine benthic communities dominated by epifaunal (surface dwelling) or semi-infaunal animals to a more infaunal benthos. Although Vermeij [40,41] originally perceived this "revolution" as an event that began during the Jurassic, it clearly began during the Late Triassic and accelerated during the Early Jurassic (Pliensbachian-Toarcian) [42-46]. Lucas and Tanner [47], in reviewing the end-Triassic extinctions, concluded that they have "no clear relationship to the Mesozoic marine revolution." However, the conulariids, who are known to have been preyed on by durviorous predators during the Paleozoic [48,49], may prove to be an exception to that generalization. Indeed, the late Paleozoic-Triassic conulariids were generally small and relatively thick shelled, an adaptation to durivorous predators that may have served them well until the onset of the Mesozoic marine revolution. 
Perhaps most amazing is that conulariid fossils have been collected and studied for more than 180 years, yet their Triassic record is so limited, even though the Triassic shelly benthos is well studied globally. Perhaps that does indicate that Triassic conulariids truly were a relict group who survived the Permo-Triassic extinction only to be eliminated by new guilds of durivorous predators that appeared during the Late Triassic.

\section{Acknowledgments}

My search for the "conulariid" fossil described by Bradford Willard began in 2004 at Lehigh University and met success in 2011 at the National Museum of Natural History. I am grateful to Michael Brett-Surman, Mark Florence, Charyl Ito and Frank Pazzaglia for helping me find that fossil. Hugo Bucher, Jim Jenks, Heinz Kozur, Karl Krainer and Heyo Van Iten helped me with the literature. Heinz Kozur shared information about an unpublished Triassic conulariid and clarified the age of Bittner's conulariid from the Triassic of Austria. Heinz Kozur and Heyo van Iten read an earlier version of the manuscript, and their comments, plus those of two anonymous reviewers, improved its content and clarity.

\section{References}

1. Leme, J.M., de; Simões, M.G.; Rodrigues, S.C.; van Iten, H.; Marques, A.C. Major developments in conulariid research: Problems of interpretation and future perspectives. Ameghiniana 2008, 45, 407-420.

2. Tanner, L.H.; Lucas, S.G.; Chapman, M.G. Assessing the record and causes of Late Triassic extinctions. Earth-Sci. Rev. 2004, 65, 103-139.

3. Nudds, J.R.; Sepkoski, J.J., Jr. Coelenterata. In The Fossil Record; Benton, M.J. Ed.; Chapman and Hall: London, UK, 1993; Volume 2, pp. 101-124.

4. Willard, B. The Harvey Bassler Collection of Peruvian Fossils; Lehigh University: Bethlehem, PA, USA, 1966; p. 255.

5. Willard, B.A. Cretaceous conularid from Peru. Penn. Acad. Sci. 1967, 40, 87-89.

6. Moore, R.C., Lalicker, C.G.; Fischer, A.G. Invertebrate Fossils; McGraw-Hill Book Company, Inc.: New York, NY, USA, 1952; p. 766.

7. Van Iten, H.; Leme, J.; Simões, M.G.; Marques, A.C.; Collins, A.G. Reassessment of the phylogenetic position of conulariids (?Ediacaran-Triassic) within the subphylum Medusozoa (phylum Cnidaria). J. Syst. Palaeontol. 2006, 4, 109-118.

8. Van Iten, H.; Leme, J.M. de; Rodrigues, S.C.; Simões, M.G. Reinterpretation of a conulariid-like fossil from the Vendian of Russia. Palaeont. 2005, 48, 619-622.

9. Van Iten, H.; Vyrhlasová, Z. Conulariids. In The Great Ordovician Biodiversification Event; Webby, B.D., Paris, F., Droser, M.L., Percival, I.G., Eds.; Columbia Universitry Press: New York, NY, USA, 2004; pp. 119-123.

10. Van Iten, H. Written communication. Hanover, IN, USA, 2012.

11. Moore, R.C.; Harrington, H.J. Conulata. In Treatise on Invertebrate paleontology Part F Coelenterata; Moore, R.C., Ed.; Geological Society of America: Boulder, CO; University of Kansas Press: Lawrence, KS, USA, 1956; pp. F54-F66. 
12. Babcock, L.E.; Feldman, R.M. Mysterious fossils. Earth Sci. 1984, 37, 16-17.

13. Finks, R.M. Conularia in a sponge from the West Texas Permian. J. Paleontol. 1955, 29, 831-836.

14. Harland, T.L.; Pickerill, R.K. Epizoic Schizocrania sp. from the Ordovician Trenton Group of Quebec, with comments on mode of life of conulariids. J. Paleontol. 1987, 61, 844-849.

15. Van Iten, H. Repositories of and additional comments on Permian sponge specimens containing molds of Paraconularia. J. Paleontol. 1991, 65, 335-337.

16. Brood, K. Morphology, structure, and systematics of the conulariids. GFF 1995, 117, 121-137.

17. Simões, M.G.; Mello, L. H. C. de; Rodrigues, S.C.; Leme, J. de M.; Marques, A.C. Conulariid taphonomy as a tool in paleoenvironmental analysis. Rev. Bras. Geociênc. 2000, 30, 757-762.

18. Waterhouse, J.B. Permian and Triassic conulariid species from New Zealand. J. Roy. Soc. New. Zeal. 1979, 9, 475-489.

19. Babcock, L.E. A new Ordovician conulariid from Oklahoma? Okla. Geol. Notes 1985, 45, 66-70.

20. Babcock, L.E.; Gray, J.; Boucot, A.J.; Himes, G.T.; Siegele, P.K. First Silurian conulariids from Paraguay. J. Paleont. 1990, 64, 897-902.

21. Benavides-Cáceres, V.E. Cretaceous system in Northern Peru. B.Am.Mus.Nat.Hist. 1956, 108, 353-494.

22. Dhondt, A.V.; Jaillard, E. Cretaceous bivalves from Ecuador and northern Peru. J. South Amer. Earth Sci. 2005, 19, 325-342.

23. Jaillard, E., Bengtson, P.; Dhondt, A.V. Late Cretaceous marine transgressions in Ecuador and northern Peru: A preliminary stratigraphic framework. J. S. Am. Earth Sci. 2005, 19, 307-323.

24. Cox, L.R.; Newell, N.D.; Branson, C.C.; Casey, R.; Chavan, A.; Coogan, A.H.; Dechaseaux, C.; Fleming, C.A.; Haas, F.; Hertlein, L.G.; et al. Systematic descriptions. In Treatise on Invertebrate Paleontology; Moore, R.C., Ed.; Geological Society of America: Boulder, CO, USA; University of Kansas: Lawrence, KS, USA, 1969; Part N, Mollusca 6, Bivalvia, Volume 1, pp. N245-N489.

25. Lucas, S.G.; Krainer, K.; Spielmann, J.A.; Durney, K. Cretaceous stratigraphy, paleontology, petrography, depositional environments, and cycle stratigraphy at Cerro de Cristo Rey, Doña Ana County, New Mexico. New Mex. Geol. 2010, 32, 103-130.

26. Thomas, G.A. Notoconularia, a new conularid genus from the Permian of Eastern Australia. J. Paleontol. 1969, 43, 1283-1290.

27. Argéliez, M. Letter to Élie de Beaumont. Soc. Géol. Fr. Bull. 1856, 13, 186-188.

28. Sandberger, G. Die Flossenfüsser der Pteropoda der ersten Erdbildungs-Epoche. Conularia Coleoprion. Neues Jahrb. Mineral Jahrg. 1847, 1847, 8-25.

29. Bittner, A. Eine Triadische Conularia. Kaiserl.-königl. Geol. Reichanstalt Verhand. 1890, 9, 177-178.

30. Osswald, K. Mesozoische Conulariiden. Cent. Mineral. 1918, 21-22, 337-344.

31. Sinclair, G.W.; Richardson, E.S. A bibliography of the Conularida. B. Am. Paleontol. 1954, 34(145), 1-143.

32. Bittner, A. Conularia in der Trias. Kaiserl.-königl. Geol. Reichanstalt Verhand. 1878, 12, 281-282.

33. Diener, C. Triassic faunas of Kashmir. Geol. Surv. India Mem. Palaeontol. Indic. New Ser. 1913, 5(2), 1-133.

34. Krystyn, L.; Balini, M.; Nicora, A. Lower and Middle Triassic stage and substage boundaries in Spiti. Albertiana 2004, 30, 40-53.

35. Trechmann, C.T. The Trias of New Zealand. Q. J. Geol. Soc. 1918, 73, 165-246. 
36. Sugiyama, T. Studies on the Japanese Conularida. Geol. Soc. Jpn. 1942, 49, 390-399.

37. Hagdorn, H.; Campbell, H.J. Paracomatula triadica sp. nov.-An early comatulid crinoid from the Otapirian (Late Triassic) of New Caledonia. Alcheringa 1990, 17, 1-17.

38. Kozur, H. Written communication. Budapest, Hungary, 2012.

39. Weldon, E.A.; Shi, G.R. Global distribution of Permian conulariids and palaeobiogeographical implications. Gondwana Res. 2003, 6, 791-802.

40. Vermeij, G.J. The Mesozoic marine revolution: Evidence from snails, predators and grazers. Paleobiology 1977, 3, 245-258.

41. Vermeij, G.J. Evolution and Escalation; Princeton University Press: Princeton, NJ, USA, $1983 ;$ p. 527.

42. Fürsich, F.T.; Jablonski, D. Late Triassic naticid drillholes: Carnivorous gastropods gain a major adaptation but fail to radiate. Science 1984, 224, 78-80.

43. Harper, E.M.; Skelton, P.W. The Mesozoic marine revolution and epifaunal bivalves; In Proceedings of Symposium 'Molluscan Palaeontology', 11th International Malacological Congress, Siena, Italy, 30 August-5 September 1992; National Museum of Natural History: Leiden, The Netherlands, 1993; Issue 2, pp. 127-153.

44. Harper, E.M.; Forsythe, T.W.; Palmer, T. Taphonomy and the Mesozoic marine revolution: Preservation state masks the importance of boring predators. Palaios 1998, 13, 352-360.

45. Nützel, A. The Late Triassic species Cryptaulax? bittneri (Mollucsa: Gastropoda: Procerithiidae) and remarks on some aspects of the early Mesozoic marine revolution. Paläontol. Z. 2002, $76,57-63$.

46. Hautmann, M. Early Mesozoic evolution of articular bivalve ligaments and its implications for the timing of the 'Mesozoic marine revolution'. Lethaia 2004, 37, 165-172.

47. Lucas, S.G.; Tanner, L.H. Reexamination of the end-Triassic mass extinction. In Mass Extinction; Elewa, A.M., Ed.; Springer-Verlag: Berlin, Germany, 2008; pp. 66-103.

48. Babcock, L.E., Feldmann, R.M.; Wilson, M.T. Teratology and pathology of some Paleozoic conulariids. Lethaia 1987, 20, 93-105.

49. Mapes, R.H., Fahrer, T.R.; Babcock, L.E. Sublethal and lethal injuries of Pennsylvanian conulariids from Oklahoma. J. Paleontol. 1989, 63, 34-37.

(C) 2012 by the authors; licensee MDPI, Basel, Switzerland. This article is an open access article distributed under the terms and conditions of the Creative Commons Attribution license (http://creativecommons.org/licenses/by/3.0/). 